\title{
Co-Authorship Pattern in Research on Energy Sector: A Social Network Analysis
}

\author{
Siti Aisyah ${ }^{1^{*}}$, Ria Hardiyati ${ }^{2}$ \\ ${ }^{1}$ Universitas Muhammadiyah Surakarta, Faculty of Economics and Business \\ ${ }^{2}$ Research Center for Science and Technology Development \\ Indonesian Institute of Sciences \\ *Corresponding Author: sa150@ums.ac.id
}

Recieved: February 2019 | Revised: February 2019 | Accepted February 2019

\begin{abstract}
A nation's capacity to provide clean and affordable energy is crucial for the development of its economy. Indonesia energy mix still rely heavily on fossil fuels, but a concerted effort to explore a more sustainable energy has been laid out by the government, including promoting studies and providing incentives for research in the area of sustainable energy. This paper tries to examine the trend of energy research in Indonesia, the theme of research in the field of energy and to find out which institution has conducted a rigorous research and actively producing publications in this field. The study uses data of international research publications from World of Science (WOS) during 1997-2014. Data Analysis using Social Network Analysis (SNA) with UCINET, NetDraw, and VOSViewer software. The result shows that the number of international publications on energy in Indonesia are increasing and most publications are of research collaboration with institutions from other country. Based on keywords that frequently appear which are biomass, biodiesel, and ethanol, it can be concluded that popular research theme on energy in Indonesia is renewable energy. This paper concludes with the findings on institutions with the highest rank in renewable energy publications, those are Institut Teknologi Bandung (ITB), Universitas Gadjah Mada (UGM), Institut Pertanian Bandung (IPB), and Lembaga Ilmu Pengetahuan Indonesia/Indonesian Institute of Sciences (LIPI). Research collaborations with institutions from around the globe will improve the performance of research and development bodies in Indonesia, this in turn will benefit the economy in the long run through knowledge transfer and innovations on the energy sector.
\end{abstract}

Keywords: R\&D; Scientometrics; Social Network Analysis; Energy, Development Economics JEL Classification: E0, O2, K32,Z0

How to Cite: Aisyah, S., \& Hardiyati, R. (2019). Co-authorship Pattern in Research on Energy Sector: Social Network Analysis. Jurnal Ekonomi Pembangunan: Kajian Masalah Ekonomi dan Pembangunan, 20(1). doi:https://doi.org/10.23917/jep.v20i1.7735

DOI: https://doi.org/10.23917/jep.v20i1.7735

\section{Introduction}

Energy security considered to be one of the most fundamental pillar for a country's economic growth. Serve as enabling element for economic activities, affordable energy is a catalyst for government of developing countries in poverty alleviation attempts (REN21, 2009) as well as a reason to hinder good quality of life stems from excessive use that lead to polluted and damaged environment. Given the considerable role, it is fairly understandable for a nation to continue seeking ways to find new source of energy, spearheaded by quality research in the field. 
Jurnal Ekonomi Pembangunan: Kajian Masalah Ekonomi dan Pembangunan, 20 (1), 2019, 50-59

The energy consumption in Indonesia is moving in an upward trend, despite the persistent fall in the population growth. Projection of GDP growth in 2015-2050 is around 5.6\% per year and $0.8 \%$ per year in average population growth, resulting in projected growth of energy demand to $4.9 \%$ per year in 2050 (MEMR, 2016). In terms of energy consumer, manufacturing and transportation sectors held the highest number in demand of energy up to 2025, while after 2025 manufacturing industry is projected to be the sole player in the highest energy consumer.

Every year, the Government of Indonesia (GoI) invests in research and development (R\&D) in all science and technology sectors. The investment is manifested in the form of an $R \& D$ infrastructure and budget. From 1969-2013, the government's R\&D budget has increased, despite the fact that by ratio against the Gross Domestic Income (GDI) and National Budget the number has taken a downturn, which is $0.06 \%$ of the GDI and $0.4 \%$ of the National Budget (Pappiptek, 2014). The National Budget allocated for R\&D in energy is fairly significant, which is visible, among others, from the high budget allocation for the Ministry of Energy and Mineral Resources (EMR) R\&D budget which amounted almost IDR200 billion (Pappiptek, 2014).

Numerous studies have shown various degree of the relationship between energy consumption and economic growth. Some argue that energy has no significant impact to the growth of the economy (Cheng, 1995). To, Wijeweera, and Charles (2012) findings elaborated that the relationship between energy consumption and Australian economic growth is not statistically significant. Others, however found that there is a strong causality relationship between the two. Since the late 70 's economist highlighted the effect of energy consumption on growth. Archambault, Caruso, Côté, and Larivière (2009); Kraft and Kraft (1978) all of their studies confirmed that energy consumption leads to positive economic growth.

Indonesia had taken a more serious attempt to curb the ever growing need of national energy when the traditional energy sources (oil, gas, coal) is increasingly deteriorating. The trans-boundary, inter-disciplinary nature of national energy management requires high level of coordination among stakeholders. The establishment of National Energy Board with the main task to formulate National Energy Policy as mandated by Law No 30/2007 on energy, reflects their serious commitment in tackling energy security issues. Advocating scientific research in the field of sustainable energy will pave the way to improve national energy mix and in turn sustainable growth of Indonesian economy.

One of the scientometric indicators to measure the R\&D performance is the research output, such as research publication (Pouris \& Pouris, 2009). However, the output in energy research R\&D in the form of publication remains low. The number is compared with that of other sectors in the local publication database, The Indonesian Publication Index (IPI), which formerly was known as Portal Garuda (id.portalgaruda.org), and the Scopusindexed international publication database, the Scimagojr (www.scimagojr.com). The IPI data on March 252016 showed that there were only 1,272 articles published in energy sector. This number is lower when compared with publication from other sectors, such as engineering $(4,187)$, economics $(5,231)$, agriculture $(1,333)$, chemistry $(2,103)$, and food $(1,788)$. The similar condition is also shown by the publication data from the www.scimagojr.com which was accessed on March 25 2016. Energy sector only produced 1,444 articles, while agriculture produced 5,902 articles, chemistry 1,956, engineering 4,442, math 1,592, and physics 2,706. According to the data from the Scimagojr, the Indonesian scientific publication in energy within 1996-2014 is fairly low as compared to its neighbors, with only 1,483 articles. Malaysia, on the other hand, produced 6,607 articles, India 29,237, Singapore 4,485, Thailand 3,362, and Japan 58,739. Meanwhile, the R\&D funded from the government budget is supposed to be responsible to conduct scientific researches which directly contribute to the nation's socio-economic goals (Gupta, 2013). On the other hand, Indonesia's dependence on fossil 
fuel reflects Indonesia's R\&D performance in energy sector which has yet produced any notable innovation in renewable energy.

\section{Literature Review}

R\&D output in the form of scientific publication often occurs as the result of research collaboration or co-authorship. The nature of research in energy advancement is wideranging, other key sectors such as economics, politics and environmental issues are involved which create a challenge in referring energy research as a homogenous domain (Changlin, 2007). Scientometrics as the science that measures and analyzes science and technology has highlighted topics, such as the identification of bibliometrics pattern and the co-authorship relations trend. The scientometrics study in Indonesia is still limited, which include, among others, Hartinah, Tupan, Iswanti, Rahartri, and Prahastuti (2012), who conducted a research on the energy sector development map according to literatures such as research report, thesis, etc. Other than energy sector, she also conducted similar research in health sector. Yoganingrum (2004) used the bibliometrics analysis to map the scientific researches in Indonesia. Furthermore, Lukman (2012) mapped the research report in the LIPI Biology Research Center by utilizing the bibliometrics analysis and co-word analysis. Unlike the research conducted by Hartinah et al., Yoganingrum and Lukman's research does not use the bibliometrics analysis, but rather, the social network analysis (SNA). Unlike previous studies which employs bibliometrics analysis in research of energy sector, this study tries to investigate the research output in energy sector in Indonesia by utilizing Social Network Analysis (SNA).

Scientometrics research in energy has been conducted in India by Ranganathan \& Balasubramani (2014). Ranganathan \& Balasubramani mapped the researches on India's green energy by using the Web of Science (WoS) publication data, which was then analyzed by using the bibliometrics method, and classified them by using Histcite Software. On the other hand,
Sivasekaran (2015) used the WoS publication data 2001-2013 and bibliometrics methods to map India's publication on the renewable energy.

The contribution of $R \& D$ in energy sector can be seen by conducting a scientometrics study which assessment is based upon the research publication. Therefore, this research aims to examine the trend of the results of energy sector researches in Indonesia in1997-2014, a research theme that was frequently conducted in Indonesia, and identify which institutions are active in energy sector research publication.

\section{Method}

As a quantitative research, it utilizes the data on Indonesia' international research publication in the Web of Science, which is accessed on the www.webofknowledge.com. The data taken is the scientific publication data, one of the writers of which is affiliated to Indonesia for 18 years (19972014). After the data was collected, a cleaning process was conducted by checking the consistency and harmonization of the names and institutions of origin. The data was then processed by using UCINET, Netdraw, and VOSviewer software to obtain the network, and afterwards was analyzed by using the social network analysis.

The Concept of Social Network Analysis

Scientometrics is a branch of science which measures and analyzes science and technology. One of its focuses is the identification of bibliometrics pattern. The social network analysis started from the premise that the relations between social actors can be described in a graph (Liu, Bollen, Nelson, \& de Sompel, 2005). The social network analysis has been frequently conducted in various scientific branches (Barabási \& Frangos, 2002; Otte \& Rousseau, 2002; Wasserman \& Faust, 1994). The social network analysis is used to build a network which consists of nodes which represent actors (authors/institutions), and edge which represents actor's interaction (coauthorship). Nascimento, Sander, and Pound (2003) measures the actor's activity by using the average distance of the path's length in the network produced. In the social network 
analysis, the distance measurement used in the sociogram is the geodesic distance, which is adopted from the Graph Theory. The geodesic distance is the shortest path between two actors. If one actor is isolated or unreachable or has no relations whatsoever with another actor, the actor's geodesic distance is infinite or undefined (Wasserman \& Faust, 1994).

Freeman (1978) argued that the centrality in SNA is one of the measures to see the position of an actor/group in a sociogram. The degree centrality actor is the number of direct relations that belong to an actor. The other centrality measure is the closeness and betweenness. Closeness measures the proximity between actors/nodes. Betweenness of an actor is the number of an actor's presence in the geodesic (shortest path) of the other actor pairs, compared with the number of the actor pair's geodesic in the network. An individual with the highest betweenness is considered as the actor who holds the control of the information flow in the network.

Scientometrics can be used to measure the R\&D performance. One of the indicators of the R\&D performance measurement is the
R\&D output. This research will elaborate about the $R \& D$ output which is research publication, particularly the publication of research in energy sector found in the WoS. The data on the energy sector publication that has been collected will then go through a cleaning process which is conducted by checking the consistency and conducting harmonization between the names of the author and institution, as well as by removing duplicated data. Subsequently, by using UCINET, Netdraw, and VOSviewer, the co-authorship social netwrok of the authors collaboration, institution, and keywords will be generated. The network will afterwards be analyzed using the social network analysis to count the centrality of the institutional network: the degree centrality, closeness, and betweenness, as well as by looking at the keywords with the high frequency of appearance. The institution with a high degree centrality value, small closeness, and high betweenness, are the central actors in the network. The keyword network or co-word is used to analyze the themes and relations between keywords in the network (Small, 1973).

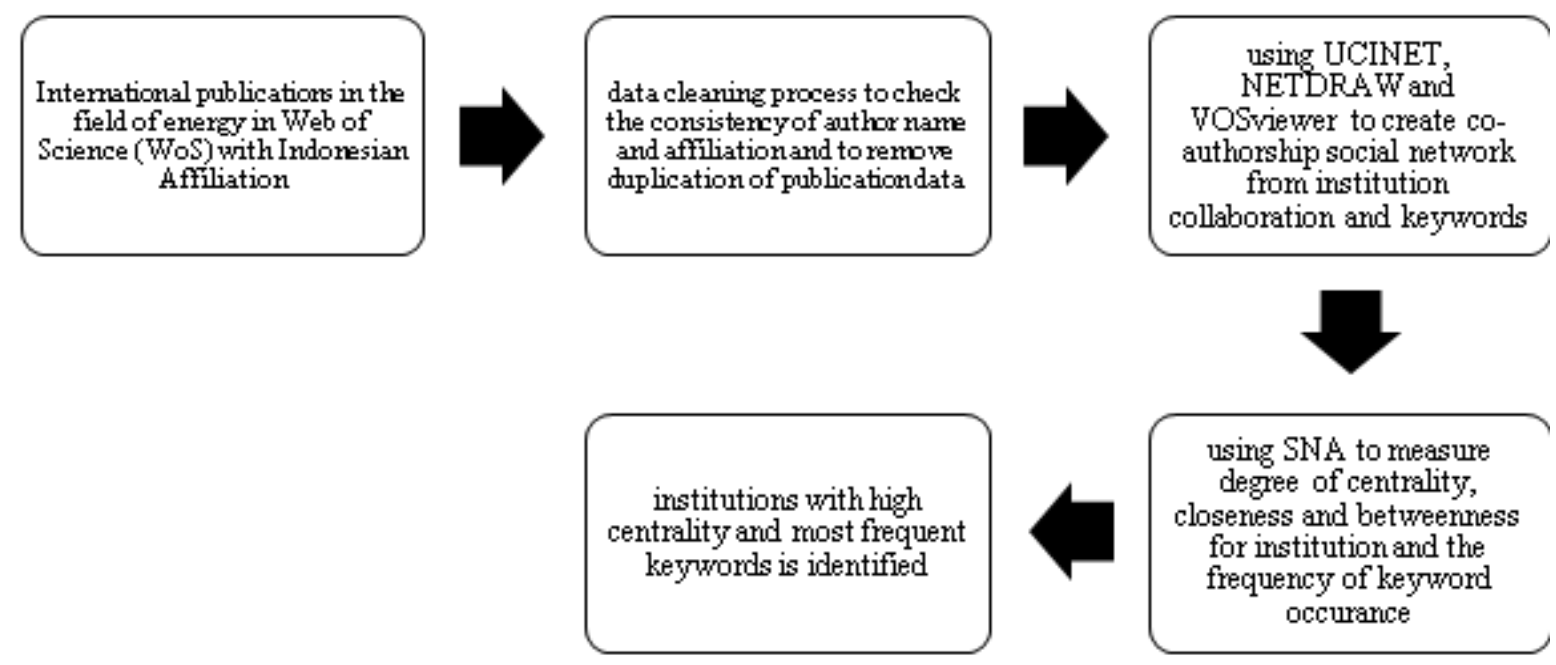

Figure 1. The Framework of Social Network Analysis 
4. Results And Discussions

4.1 The Trend of the Result of Research on Energy Sector in Indonesia

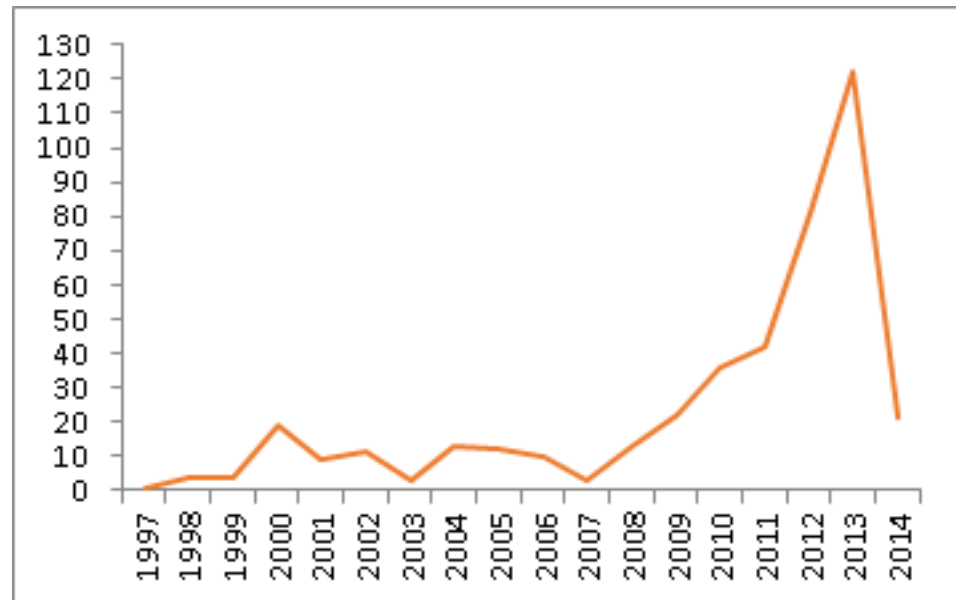

Figure 2. Number of Indonesia publication in the field of energy in WoS in 1997-2014

Table 1. Average Number of Authors in an Article

\begin{tabular}{cccc}
\hline $\begin{array}{c}\text { Number of author } \\
\text { in an article }\end{array}$ & $\begin{array}{c}\text { Number of } \\
\text { article }\end{array}$ & $\begin{array}{c}\text { Number of author } \\
\text { in an article }\end{array}$ & $\begin{array}{c}\text { Number of } \\
\text { article }\end{array}$ \\
\hline 1 & 64 & 6 & 33 \\
2 & 43 & 7 & 17 \\
3 & 57 & 8 & 6 \\
4 & 57 & 9 & 6 \\
5 & 35 & 10 & 5 \\
\hline
\end{tabular}

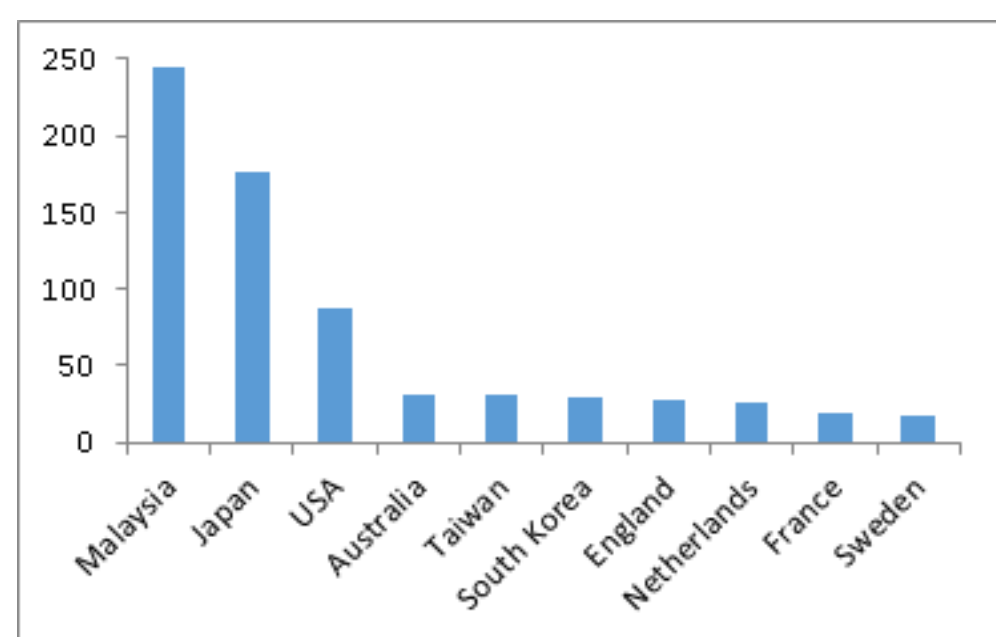

Figure 3. Ten countries with the highest collaboration with Indonesian research agency

One of the medium to see the trend of the energy sector research result in Indonesia is by looking at the number of its international

publication. Figure 2 shows that the number of Indonesia's international publication tends to increase (WoS). This is particularly true since

Jurnal Ekonomi Pembangunan, ISSN 1411-6081, E-ISSN 2460-9331 
2008. It might be related to the increase in education budget (Lakitan, Hidayat, \& Herlinda, 2012). The number significantly increased in 2009-2013, and yet in 2014, the graph declined, which is likely due to the data being collected in the mid December 2014. The trend of increasing number of international publication in energy sector is aligned with the increase of the number of international publication as a whole (Pappiptek, 2014).

In term of number, the research publication has been increasing since 2008. However, the number is still far behind if compared to those of Malaysia, Singapore, and Thailand. Indonesia ranked fourth in ASEAN in term of number of publication (Pappiptek, 2014).

The number of Indonesia's international publication in energy sector, according to WoS, is 323 publications, with 216 resulted from international collaboration with institution from another country, 43 from research collaboration between institutions in Indonesia, and 64 publications authored by a single author. The distribution of the author number in a paper can be seen on Table 1. According to the data, the number of publication and distribution of author number, it can be assumed that the majority of researches in energy sector in Indonesia are the ones conducted in collaboration with foreign institution. As shown on Figure 3, the countries that most intensely collaborate with Indonesian institutions are Japan, followed by Malaysia. It can be said, then, that one of the means to enhance the number of research publication is collaboration. In addition, research collaboration can also accelerate the transfer knowledge process in the science and technology sector.

\subsection{Research Topics Frequently Conducted in Indonesia}

By utilizing UCINET, NETDRAW and VOSviewer softwares, the 323 publications in energy sector are processed to obtain the keywords used in those publications. The result can be seen on Figure 4. The most frequently used keywords are identified by looking at the frequency of such keywords. Words such as "BIOMASS", "ENERGY", and "BIODIESEL" have bigger size in Figure 4, which show that they have higher frequency in the network as well. Furthermore, the value of frequency of the most frequent 20 keywords in the network can be seen on Table 2 .

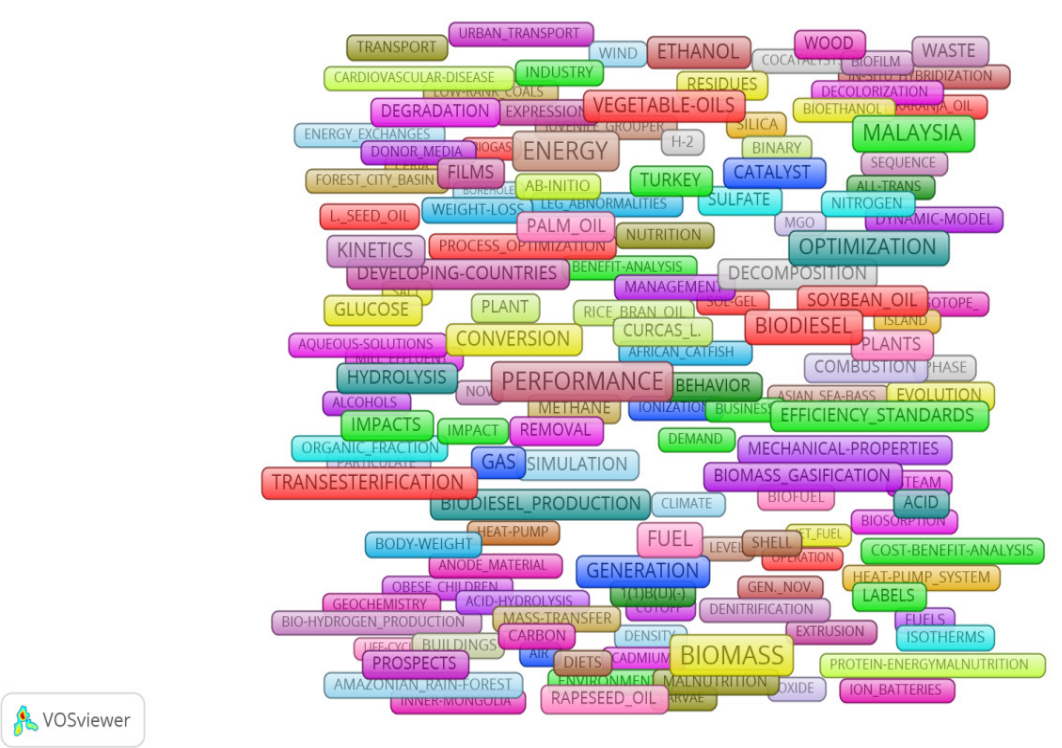

Figure 4. co-word network in International publication in energy sector 
Avalaible online at http://journals.ums.ac.id, Permalink/DOI: 10.23917/jep.v20i1.7735

Jurnal Ekonomi Pembangunan: Kajian Masalah Ekonomi dan Pembangunan, 20 (1), 2019, 50-59

Tabel 2. The Most Frequenty Used Keywords

\begin{tabular}{lrrrr}
\hline \multicolumn{1}{c}{ keywords } & frequency & & keywords & frequency \\
\cline { 5 - 5 } Biomass & 240 & & Temperature & 104 \\
Performance & 226 & & Generation & 100 \\
Energy & 202 & & Reactor & 100 \\
Malaysia & 160 & & Water & 100 \\
Biodiesel & 138 & & Vegetable-Oils & 94 \\
Pyrolysis & 136 & & Ethanol & 88 \\
Model & 132 & & Kinetics & 88 \\
Fuel & 124 & & Transesterification & 88 \\
Optimization & 124 & & Gas & 86 \\
Conversion & 114 & & Simulation & 82 \\
& & & &
\end{tabular}

The keyword network or co-word can be used to see the topics of research that are frequently conducted in Indonesia, i.e. by looking at the most frequently occurring keywords (Small, 1973). It can be concluded, then, that the researches on energy that are conducted in Indonesia throughout 1997-2014 have been growing toward researches on renewable energy. This is proven with the occurrence of keywords such as biomass, biodiesel, and ethanol in the top 20 search queries. It also means that the Government's policy in energy consumption, which is stipulated in the Presidential Regulation No.5/2006 has been getting supports. The Government has set a target of renewable energy consumption of more than $5 \%$.

\subsection{Identifying the Most Active Institution in Energy Research}
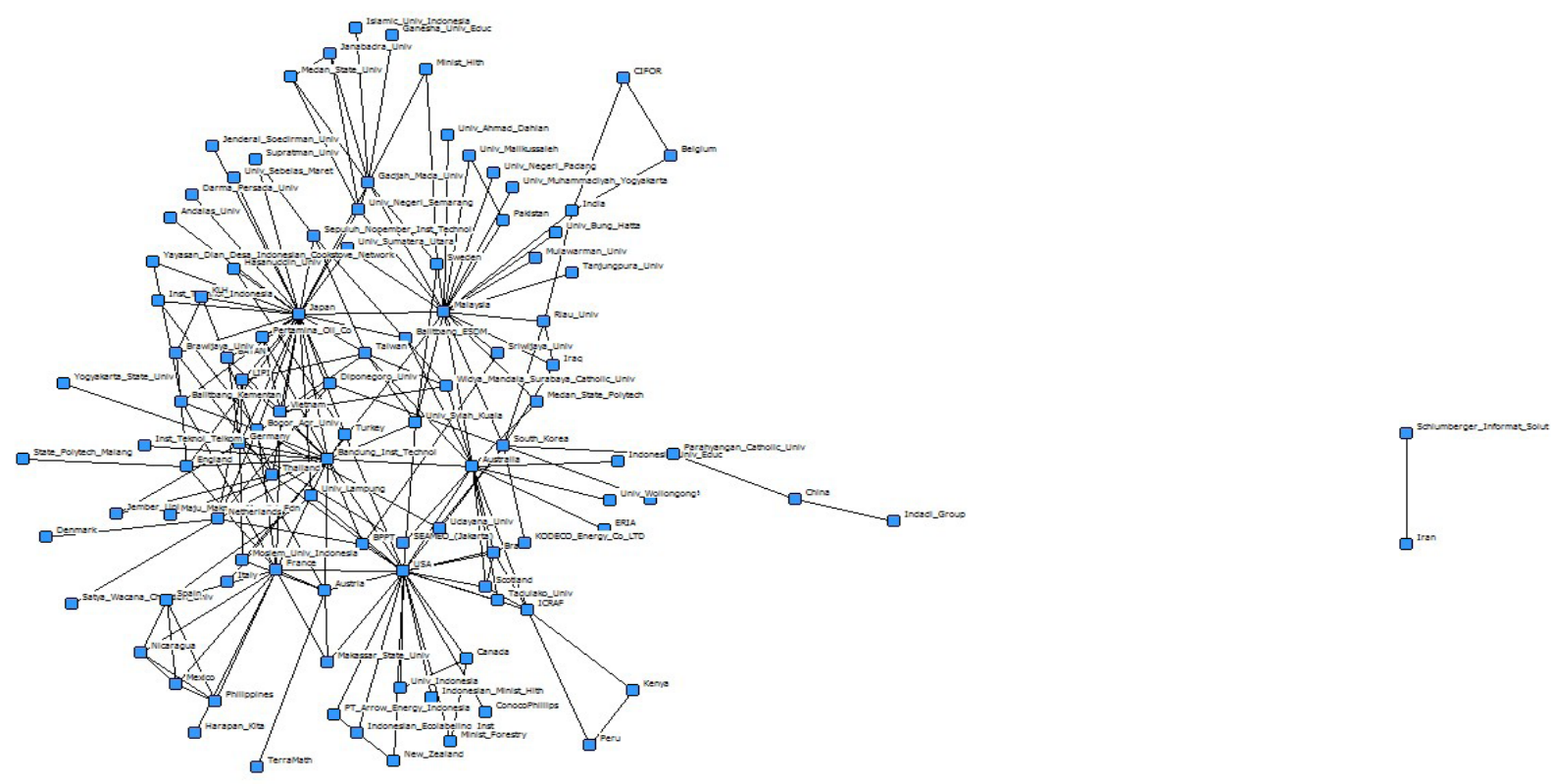

Figure 5. Social network of institutions in international energy publication 
Avalaible online at http://journals.ums.ac.id, Permalink/DOI: 10.23917/jep.v20i1.7735

Jurnal Ekonomi Pembangunan: Kajian Masalah Ekonomi dan Pembangunan, 20 (1), 2019, 50-59

Table 3. Ten Countries with the Highest Centrality in Co-authorship Network

\begin{tabular}{lll}
\hline \multicolumn{1}{c}{ Degree centrality } & \multicolumn{1}{c}{ Closeness } & Betweenness \\
\hline Japan & Malaysia & Malaysia \\
USA & Japan & Japan \\
Malaysia & USA & USA \\
Australia & Australia & Australia \\
France & Korea Selatan & Korea Selatan \\
Germany & France & France \\
Korea Selatan & Turkey & Germany \\
Austria & Thailand & Netherlands \\
Netherlands & Germany & India \\
Taiwan & Austria & Austria \\
\hline
\end{tabular}

Table 4. Ten Institutions with the Highest Centrality in Co-authorship Network

\begin{tabular}{lll}
\hline \multicolumn{1}{c}{ Degree centrality } & \multicolumn{1}{c}{ Closeness } & \multicolumn{1}{c}{ Betweenness } \\
\hline ITB & ITB & ITB \\
UGM & Univ. Syiah Kuala & UGM \\
IPB & IPB & ICRAF \\
ICRAF & Univ. Lampung & Unika Parahyangan \\
LIPI & LIPI & IPB \\
Univ. Negeri Semarang & UGM & Univ. Syiah Kuala \\
Univ. Syiah Kuala & Univ. Diponegoro & Univ. Diponegoro \\
BPPT & BPPT & Univ. Negeri Semarang \\
Balitbang Kementan & BATAN & Univ. Lampung \\
Univ. Brawijaya & Univ. Negeri Semarang & BPPT \\
\hline
\end{tabular}

There are 323 publications in energy sector that is processed using the UCINET and NETDRAW and created the institutional social network with 103 institutions and 394 relations, as seen on Figure 5. The established network is the one that is based on the co-authorship or collaboration between authors in one paper. Table 3 and 4 show the size of centrality of such an institutional social network. Countries with the best centrality size are the ones which collaborate frequently with institutions in Indonesia, such as Malaysia and Japan.

The domestic institutions with the best centrality size are those with the best research collaboration, both with other Indonesian as well as foreign institutions. The institutions are: ITB, UGM, IPB, and LIPI. The four institutions are the top 5 institutions with the most international publication, according to the WoS data in 2001-2013 (Pappiptek, 2014). Thus, it is safe to conclude that research in energy sector has become one of the focuses in the aforementioned four institutions.

Best centrality size indicates that an institution is active in research publication in energy sector. The centrality size can show the role of each institution in the social network. ITB, for instance, thrives in the three centrality sizes, namely the degree centrality, closeness, and the betweenness. By using the social network analysis, ITB's role in energy sector research can be construed as an institution with numerous collaborations and one that has a good closeness with other institutions, as well as an institution which holds control over the flow of information in the research network in energy sector. 


\section{Conclusion}

The number of Indonesia's international publication in energy in 1997-2014 has been steadily increasing. One of the method to increase the number of research publication is by conducting research collaborations with both domestic and foreign institutions. In addition, research collaboration can also accelerate the transfer knowledge process in science and technology. The study found that the most common research topic conducted in the energy sector in Indonesia is renewable energy. This result indicates support to the Government's target to have more than $5 \%$ renewable energy consumption in 2025 . The institutions that are active in research publication in energy sector are: ITB, UGM, IPB, and LIPI. The energy sector, particularly that of renewable energy, is the research focus of the four major institutions. If the R\&D institutions in Indonesia are to conduct more collaboration in energy sector research, the number of research publication in energy sector will steadily increase. The number of the increasing research publication also shows the increasing $R \& D$ performance.

Research in energy especially the new and renewable energy will increasingly play a bigger role in forging the economic growth of Indonesia, since the depletion of fossil-based energy sources left the country with no choice but to explore alternative sources of energy. Indonesia is prone to face energy crisis due to the high growth of energy demand and at the same time the production capacity of traditional energy sources continuously declining. The policy implication from this study is Indonesia need to encourage research in energy particularly that of renewable energy by allocating more budget for energy R\&D and constructing a sound energy infrastructure.

\section{Acknowledgement}

The authors would like to express gratitude to Pappiptek LIPI for assistance with the data.

\section{Reference}

Archambault, É., Caruso, J., Côté, G., \& Larivière, V. (2009). Bibliometric Analysis of Leading Countries in Energy Research. In Proceedings of the 12th International Conference of the International Society for Scientometrics and Informetrics (ISSI), Rio de Janeiro, Brazil (pp. 14-17).

Barabási, A.-L., \& Frangos, J. (2002). Linked: the new science of networks science of networks. Basic Books.

Changlin, G. (2007). China National Energy Startegy and Policy2020: Policy Research on EnergyResearch and Development. Beijing: China Sustainable Energy Program. Retrieved January 2014 from Www. Efchina. Org.

Cheng, B. S. (1995). An investigation of cointegration and causality between energy consumption and economic growth. The Journal of Energy and Development, 21(1), 73-84.

Freeman, L. C. (1978). Centrality in social networks conceptual clarification. Social Networks, 1(3), 215-239.

Gupta, B. M. (2013). Bangladesh: A scientometric analysis of national publications output in S\&T, 2001-10. DESIDOC Journal of Library \& Information Technology, 33(1).

Hartinah, S., Tupan, T., Iswanti, S., Rahartri, R., \& Prahastuti, S. (2012). Peta perkembangan bidang energi berdasarkan literatur kelabu di indonesia. BACA: Jurnal Dokumentasi Dan Informasi, 30(2), 139-152.

Kraft, J., \& Kraft, A. (1978). On the relationship between energy and GNP. The Journal of Energy and Development, 401-403.

Lakitan, B., Hidayat, D., \& Herlinda, S. (2012). Scientific productivity and the collaboration intensity of Indonesian universities and public $R \& D$ institutions: Are there dependencies on collaborative R\&D with foreign institutions? Technology in Society, 34(3), 227-238.

Liu, X., Bollen, J., Nelson, M. L., \& de Sompel, H. (2005). Co-authorship networks in 
Jurnal Ekonomi Pembangunan: Kajian Masalah Ekonomi dan Pembangunan, 20 (1), 2019, 50-59

the digital library research community. Information Processing \& Management, 41(6), 1462-1480.

Lukman, B. (2012). Analisis bibliometrika berdasarkan pendekatan co-words: pemetaan laporan hasil penelitian pusat penelitian biologi-LIPI. Bogor: Institut Pertanian Bogor.

Nascimento, M. A., Sander, J., \& Pound, J. (2003). Analysis of SIGMOD's co-authorship graph. ACM SIGMOD Record, 32(3), 8-10. https:// doi.org/10.1145/945721.945722

Otte, E., \& Rousseau, R. (2002). Social network analysis: a powerful strategy, also for the information sciences. Journal of Information Science, 28(6), 441-453.

Pappiptek. (2014). Indikator Iptek Indonesia 2013. Pappiptek LIPI.

Pouris, A., \& Pouris, A. (2009). The state of science and technology in Africa (2000--2004): A scientometric assessment. Scientometrics, 79(2), 297-309.

Ranganathan, C., \& Balasubramani, R. (2014). Scientometric profile of research activities on green energy: An Indian perspective. International Journal of Research in
Applied, Natural and Social Sciences, 2(1), 23-30.

Renewable Energy Policy Network for the 21st Century (REN21). (2009). Renewables. Global Status Report. 2009 Update. Paris.

Sivasekaran, K. (2015). India's Contribution on Renewable Energy Research Output: A Scientometric Study. Journal of Advances in Library and Information Science, 4(4), 311-316.

Small, H. (1973). Co-citation in the scientific literature: Anew measure of the relationship between two documents. Journal of the American Society for Information Science, 24(4), 265-269.

To, H., Wijeweera, A., \& Charles, M. B. (2012). Energy consumption and economic growth-The case of Australia. Business School, Southern Cross University.

Wasserman, S., \& Faust, K. (1994). Social network analysis: Methods and applications (Vol. 8). Cambridge university press.

Yoganingrum, A. (2004). Bibliometrics method for knowledge mapping: An application on the scientific research in Indonesia. วารสาร บรรณารักษศาสตร์, $24(2), 1-14$. 